(C) 2014

Солонечний П. М., кандидат сільськогосподарських наук

Інститут рослинництва ім. В. Я. Юр'єва НААН

\title{
ОЦІНКА АДАПТИВНОЇ ЗДАТНОСТІ ТА СТАБІЛЬНОСТІ СОРТІВ ЯЧМЕНЮ ЯРОГО ЗА ПРОДУКТИВНІСТЮ
}

\section{Рецензент - кандидат сільськогосподарських наук С. М. Горбачова}

\begin{abstract}
Наведено результати екологічного випробування 17 сортів ячменю ярого селекиії Інституту рослинництва ім. В. Я. Юр'єва НААН. Визначено вплив факторів «умови вирощування», "генотип» та їх взаємодіï на формування маси зерна з рослини (продуктивності). Виявлено особливості параметрів середовищ пунктів екологічного випробування як фонів для оцінки генотипів. Виділено сорти з високою загальною та специфічною адаптивною здатністю за продуктивністю рослини, які є иінними джерелами для селекції ячменю ярого.
\end{abstract}

Ключові слова: ячмінь ярий, сорт, продуктивність, екологічне випробування, адаптивність, стабільність, пластичність

Постановка проблеми. Створення сортів і гібридів, які здатні максимально ефективно використовувати біокліматичний ресурс конкретного регіону, виявляти толерантність до стресових умов середовища, забезпечувати достатньо високу реалізацію генетичного потенціалу продуктивності, є стратегічним завданням сучасної селекційної науки. За постійної дії мінливих природних і антропогенних факторів нові високоадаптивні сорти мають гарантувати одержання стабільно високих врожаїв зерна [4].

Аналіз останніх досліджень і публікацій, у яких започатковано розв'язання проблеми. Причиною такої спрямованості сучасної селекційної роботи на відбір високоадаптивних форм $\epsilon$ тенденція до збільшення розриву між рекордною і середньою урожайністю найважливіших сільськогосподарських культур (звичайне співвідношення 4:1), підвищення залежності величини й якості урожаю від застосування техногенних засобів, а також від погодних флуктуацій (варіабельність урожайності за роками на 6080 \% зумовлена «витівками» природи) [1]. Складність цієї роботи полягає в тому, що існує протиріччя між високою продуктивністю генотипу та його стійкістю до несприятливих чинників навколишнього середовища. Це явище зумовлене особливостями енергетичного балансу рослинного організму, оскільки чим більше енергетичних ресурсів рослина витрачає на підтримання високої стійкості, тим менше їх залишається для формування врожаю за нормальних умов.

Більшість дослідників [6, 8-10] вважають, що для одержання достовірної оцінки адаптивного потенціалу сортів доцільно проводити їх екологічне випробування в різноманітних середовищах із використанням різних статичних методів оцінки одержаних результатів, що допомагає селекціонеру обрати найбільш врожайні та адаптовані генотипи.

Мета і завдання досліджень. Метою досліджень було визначення адаптивного потенціалу сортів ячменю ярого селекції Інституту рослинництва ім. В. Я. Юр'єва НААН в умовах екологічного випробування.

Завдання досліджень: виділити сорти з високим рівнем загальної й специфічної адаптивної здатності як найбільш цінний вихідний матеріал для селекції ячменю ярого.

Матеріали і методика досліджень. Вихідним матеріалом для досліджень слугували 17 сортів ячменю ярого селекції Інституту рослинництва ім. В. Я. Юр'єва НААН: Аграрій, Алегро, Взірець, Виклик, Здобуток, Вітраж, Вектор, Модерн, Дивогляд, Щедрий, Косар, Доказ, Перл, Парнас, Козван, Інклюзив, Етикет. 3 метою визначення їх адаптивного потенціалу було проведено екологічне випробування за трьома пунктами, що знаходились у різних грунтовокліматичних умовах: Інститут рослинництва ім. В. Я. Юр'єва НААН (східний Лісостеп), Донецька дослідна станція НААН (північний Степ) та Дослідна станція луб'яних культур Інституту сільського господарства північного сходу НААН (північно-східний Лісостеп).

Для оцінки параметрів середовищ та адаптивної здатності й стабільності генотипів використано методику А. В. Кільчевського, Л. В. Хотильової [7]. Параметри адаптивності досліджених сортів визначали за загальною $\left(3 \mathrm{~A} 3=\mathrm{v}_{\mathrm{i}}\right)$ і специфічною $\left(\mathrm{CA} 3=\sigma \mathrm{CA} 3_{\mathrm{i}}, \sigma^{2} \mathrm{CA} 3_{\mathrm{i}}\right)$ адаптивною здатністю, варіансою взаємодії генотипу та середовища $\left(\sigma_{(\mathrm{G} \times \mathrm{E}) \mathrm{g})}^{2}\right)$ відносною стабільністю генотипу $\left(\mathrm{Sg}_{\mathrm{i}}\right)$, коефіцієнтом компенсації генотипу $\left(\mathrm{K}_{\mathrm{gi}}\right)$, коефіцієнтом нелінійності генотипу $\left(l_{\mathrm{gi}}\right)$, коефіцієнтом еколо- 


\section{СІЛЬСЬКЕ ГОСПОДАРСТВО. РОСЛИННИЦТВО}

гічної пластичності $\left(\mathrm{b}_{\mathrm{i}}\right)$ та показником селекційна цінність генотипу (СЦ $\left.{ }_{\mathrm{i}}\right)$.

Для характеристики середовища, як фону для випробування сортів, розраховували наступні основні параметри: продуктивність фону $\mathrm{u}+\mathrm{d}_{\mathrm{k}}$, ефект середовища $\mathrm{d}_{\mathrm{k}}$, взаємодію «генотип $\times$ середовище»

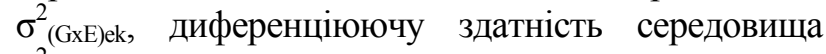

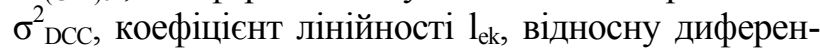
ціюючу здатність середовища $\mathrm{S}_{\mathrm{ek}}$ та коефіцієнт передбачуваності середовища $\mathrm{P}_{\mathrm{k}}$.

Коефіцієнти екологічної пластичності $\mathrm{b}_{\mathrm{i}}$ розраховано згідно 3 методикою S. A. Eberhart, W. A. Russel [7].

Результати дослідження. Згідно з методикою А. В. Кільчевського, Л. В. Хотильової [3], першим етапом оцінки адаптивних особливостей генотипів і параметрів середовищ, як фонів для добору, є дисперсійний аналіз. Проведений двофакторний дисперсійний аналіз підтвердив наявність високих достовірних відмінностей між ефектами генотипів, середовищ та їх взаємодії (табл. 1).

Дисперсійний аналіз дав змогу також визначити вплив кожного фактора та їх взаємодії на формування такого важливого показника, як продуктивність рослини (рис. 1).

Так, найбільший вплив на формування маси зерна 3 рослини мали умови вирощування -
$50,0 \%$, значно меншим був внесок генотипу сортів - 20,0 \% та взаємодії цих двох факторів 29,3 \%. У наших попередніх дослідження [5] було встановлено особливості впливу цих факторів та їх взаємодії на формування компонентів продуктивності рослини: на формування продуктивної кущистості найбільший вплив мали умови вирощування (50,9 \%), на масу 1000 зерен генотип сортів (47,7\%), а на кількість зерен 3 колосу - взаємодія цих двох факторів (40,2\%).

Методика А. В. Кільчевського, Л. В. Хотильової дає змогу оцінити умови вирощування в якості фону для оцінки генотипів. В наших дослідженнях умови пунктів екологічного випробування, як фонів для випробування сортів, істотно різнилися між собою, що дало змогу об'єктивно оцінити генотипи сортів за адаптивною здатністю й стабільністю (табл. 2).

Важливим параметром фону $є$ його продуктивність, яка оцінюється за середнім значенням усіх генотипів у певних умовах середовища або по відхиленню від загальної середньої (індекс середовища). Максимальну продуктивність генотипу сортів забезпечували в більш вологих умовах ДС луб'яних культур ІСГПС НААН, середню - в умовах Донецької ДС НААН та мінімальну - в умовах IP ім. В. Я. Юр'єва НААН.

\section{1. Двофакторний дисперсійний аналіз продуктивності рослини сортів ячменю ярого, 2013 р.}

\begin{tabular}{|c|c|c|c|c|c|}
\hline $\begin{array}{c}\text { Джерело } \\
\text { мінливості }\end{array}$ & $\mathrm{SS}$ & $\mathrm{df}$ & $\mathrm{ms}$ & $\mathrm{F}_{\text {факт }}$ & $\mathrm{F}_{01}$ \\
\hline Загальна & 32,39 & 101 & - & - & - \\
\hline Середовище & 16,09 & 2 & 8,0448 & 1013,05 & 5,06 \\
\hline Генотип & 6,40 & 16 & 0,4001 & 50,38 & 2,56 \\
\hline Взаємодія & 9,49 & 32 & 0,2967 & 37,36 & 2,18 \\
\hline Похибка & 0,41 & 51 & 0,0079 & - & - \\
\hline
\end{tabular}

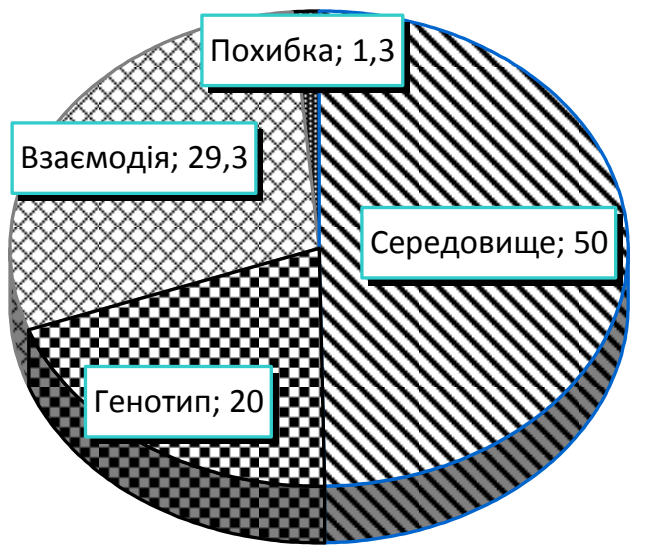

Рис. 1. Вплив чинників на формування продуктивності рослини (\%) 
СІЛЬСЬКЕ ГОСПОДАРСТВО. РОСЛИННИЦТВО

\section{2. Параметри середовища як фону для випробування сортів ячменю ярого, 2013 р.}

\begin{tabular}{|c|c|c|c|c|c|c|c|c|}
\hline Фон & $\mathrm{u}+\mathrm{d}_{\mathrm{k}}$ & $\mathrm{d}_{\mathrm{k}}$ & $\sigma_{\text {(GxE)ek }}^{2}$ & $\sigma_{\mathrm{DCCk}}$ & $1_{\mathrm{ek}}$ & $\mathrm{S}_{\mathrm{ek}}$ & $\mathrm{K}_{\mathrm{ek}}$ & $\mathrm{P}_{\mathrm{k}}$ \\
\hline IP ім. В.Я. Юр'єва НААН & 1,51 & $-0,47$ & 0,11 & 0,24 & 1,50 & 15,9 & 0,6 & 0,07 \\
\hline Донецька ДС НААН & 2,00 & 0,02 & 0,08 & 0,49 & 0,33 & 24,5 & 2,4 & 0,21 \\
\hline $\begin{array}{c}\text { ДС луб'яних культур } \\
\text { ІСГПС НААН }\end{array}$ & 2,45 & 0,47 & 0,08 & 0,46 & 0,38 & 18,8 & 2,1 & 0,15 \\
\hline
\end{tabular}

Показник диференціюючої здатності середовища $\left(\sigma_{\text {DCCK }}^{2}\right)$ дає змогу оцінити середовище в якості фону для добору генотипів. Чим більша $\sigma_{\text {DCCk }}^{2}$ середовища, тим більшим буде поліморфізм за даною ознакою. Більша диференціююча здатність середовища проявилася в умовах Донецької ДС НААН та ДС луб'яних культур ІСГПС НААН.

Для порівняльної оцінки середовищ за здатністю викликати взаємодію «генотип $\times$ середовище» розраховано варіансу $\sigma_{(\mathrm{G} \times \mathrm{E}) \mathrm{k} .}^{2}$. Найбільша варіанса взаємодії «генотип×середовище» за продуктивністю проявилася в умовах IP ім. В. Я. Юр'єва НАAН $\left(\sigma_{(\mathrm{G} \times \mathrm{E}) \mathrm{kk}}^{2}=0,11\right)$.

Відносна диференціююча здатність середовища дає можливість порівнювати результати досліджень із різним набором культур, генотипів, середовищ, ознак. Найбільша відносна диференціююча здатність середовища проявилася в умовах Донецької ДС НАAН $\left(\mathrm{S}_{\mathrm{ek}}=24,5 \%\right)$.

Значення коефіцієнта нелінійності реакції генотипу на середовище $1_{\text {ek }}$ в усіх середовищах вказує на переважно нелінійний характер мінливості показника продуктивності рослини, оскільки $1_{\mathrm{ek}} \rightarrow 1$.

Ефекти дестабілізації сильніше проявлялися в умовах Донецької ДС НААН $\left(\mathrm{K}_{\mathrm{ek}}=2,4\right)$, а ефекти компенсації сильніше проявлялися в умовах IP ім. В. Я. Юр'єва НААН $\left(\mathrm{K}_{\mathrm{ek}}=0,6\right)$.

Комплексним показником, що дає змогу ранжувати середовища за їх цінністю в якості селекційного фону, $є$ коефіцієнт передбачуваності фону $\mathrm{P}_{\mathrm{k}}$. Найвищим коефіцієнт передбачуваності фону був в умовах Донецької ДС НААН $\left(\mathrm{P}_{\mathrm{k}}=\right.$ $0,21)$, середнім - в умовах ДС луб'яних культур ICГПС НАAН $\left(\mathrm{P}_{\mathrm{k}}=0,07\right)$ і найменшим - в умовах ІР ім. В. Я. Юр'єва НААН $\left(\mathrm{P}_{\mathrm{k}}=0,07\right)$.

Погодні умови 2013 року були вкрай несприятливими для вегетації ячменю ярого, тому загальна середня маса зерна з рослини в усіх пунктах випробування становила лише 1,98 г. У кожному з пунктів екологічного випробування за продуктивністю виділилися різні сорти ячменю, але середня урожайність по всіх пунктах була найвищою у сортів Аграрій $(2,5$ г) та Козван $(2,4$ г) (табл. 3). Параметри продуктивності варіювали як за умов середовища (в залежності від зони вирощування), засвідчуючи вплив екологічного фактора «генотип×середовище», так і в межах кожного середовища між генотипами, обумовлюючи генотипову залежність.

Для селекційної роботи практичну цінність становлять сорти з високою загальною адаптивною здатністю (ЗАЗ), яка характеризує генотипи за здатністю забезпечувати максимальний рівень прояву ознаки (урожайність, продуктивність, вміст білку та ін.) по всій сукупності середовищ. Найвищі ефекти загальної адаптивної здатності за продуктивністю рослини мали генотипи сортів Аграрій $(3 \mathrm{~A} 3=0,5)$ та Козван $(3 \mathrm{~A} 3=0,4)$, а також сорти Вітраж (ЗАЗ = 0,3), Етикет (3АЗ = $0,3)$ та Перл $(3 А 3=0,3)$ (табл. 4).

Згідно з числовим значенням коефіцієнта регpeciї (коефіцієнта екологічної пластичності) $b_{i}$, генотипи сортів ячменю ярого можна поділити на категорії з низькою, середньою та високою екологічною пластичністю. Сорти Парнас, Перл, Модерн, Вітраж, Здобуток, Аграрій та Етикет за результатами наших досліджень можна віднести до сортів інтенсивного типу зі збільшеною реакцією на покращання умов вирощування $\left(b_{i}=\right.$ 1,12-2,37). Сорти Дивогляд, Косар, Виклик та Взірець характеризуються середнім рівнем екологічної пластичності $\left(b_{i}=0,92-1,05\right)$, їх продуктивність змінювалась відповідно до умов вирощування. До третьої групи входять сорти Щедрий, Вектор, Алегро, Козван, Доказ та Інклюзив, які в незначній мірі реагують на зміну умов вирощування, 3 коефіцієнтом екологічної пластичності від 0,60 до 0,86 . Наявність сортів із різним рівнем реакції на зміну умов вирощування свідчить про широку генетичну базу під час їх створення та придатності до різнопланового використання. 
СІЛЬСЬКЕ ГОСПОДАРСТВО. РОСЛИННИЦТВО

\section{3. Продуктивність (маса зерна) рослини сортів ячменю ярого в екологічному випробуванні, 2013 р.}

\begin{tabular}{|c|c|c|c|c|}
\hline \multirow[b]{2}{*}{ Сорт } & \multicolumn{4}{|c|}{ Маса зерна з рослини, г } \\
\hline & $\begin{array}{l}\text { IP ім. В. Я. Юр'єва } \\
\text { НААН }\end{array}$ & $\begin{array}{c}\text { Донецька ДС } \\
\text { НААН }\end{array}$ & $\begin{array}{c}\text { ДС луб'яних культур } \\
\text { ІСГПС НААН }\end{array}$ & Середнє \\
\hline Аграрій & 1,3 & 2,7 & 3,4 & 2,5 \\
\hline Алегро & 1,4 & 2,0 & 2,0 & 1,8 \\
\hline Вектор & 1,6 & 2,4 & 2,3 & 2,1 \\
\hline Взірець & 1,4 & 1,5 & 2,2 & 1,7 \\
\hline Виклик & 1,3 & 2,0 & 2,2 & 1,8 \\
\hline Вітраж & 1,5 & 2,7 & 2,6 & 2,3 \\
\hline Дивогляд & 1,3 & 1,8 & 2,1 & 1,7 \\
\hline Доказ & 1,4 & 2,1 & 2,1 & 1,9 \\
\hline Етикет & 1,1 & 2,5 & 3,2 & 2,3 \\
\hline Здобуток & 1,3 & 2,2 & 2,6 & 2,0 \\
\hline Інклюзив & 1,3 & 2,3 & 1,8 & 1,8 \\
\hline Козван & 2,0 & 2,5 & 2,6 & 2,4 \\
\hline Kocap & 1,9 & 2,1 & 2,7 & 2,2 \\
\hline Модерн & 1,5 & 1,3 & 2,8 & 1,9 \\
\hline Парнас & 1,1 & 1,1 & 2,1 & 1,4 \\
\hline Перл & 1,7 & 2,3 & 3,0 & 2,3 \\
\hline Щедрий & 1,5 & 1,4 & 2,0 & 1,6 \\
\hline Середнє & 1,51 & 2,00 & 2,45 & 1,98 \\
\hline $\mathrm{HIP}_{05}$ & & & & 0,18 \\
\hline
\end{tabular}

4. Параметри адаптивності сортів ячменю ярого за продуктивністю рослини, 2013 р.

\begin{tabular}{|c|c|c|c|c|c|c|c|c|c|}
\hline Сорт & $\mathrm{v}_{\mathrm{i}}$ & $\mathrm{b}_{\mathrm{i}}$ & $\sigma^{2} \mathrm{CA} 3_{\mathrm{i}}$ & $\sigma \mathrm{CA} 3_{\mathrm{i}}$ & $\mathrm{S}_{\mathrm{gi}}, \%$ & $\mathrm{CЦГ}_{\mathrm{i}}$ & $\mathrm{K}_{\mathrm{gi}}$ & $1_{\mathrm{gi}}$ & $\sigma_{(\mathrm{G} \times \mathrm{E}) \mathrm{gi}}$ \\
\hline Аграрій & 0,5 & 2,37 & 1,15 & 1,07 & 42,8 & 0,57 & 5,23 & 0,33 & 0,38 \\
\hline Алегро & $-0,2$ & 0,73 & 0,12 & 0,35 & 19,4 & 1,17 & 0,55 & 0,50 & 0,06 \\
\hline Вектор & 0,1 & 0,86 & 0,19 & 0,32 & 15,2 & 1,52 & 0,86 & 0,42 & 0,08 \\
\hline Взірець & $-0,3$ & 0,92 & 0,19 & 0,32 & 18,8 & 1,12 & 0,86 & 0,21 & 0,04 \\
\hline Виклик & $-0,2$ & 1,05 & 0,23 & 0,48 & 26,7 & 0,94 & 1,05 & 0,09 & 0,02 \\
\hline Вітраж & 0,3 & 1,30 & 0,45 & 0,67 & 29,1 & 1,09 & 2,05 & 0,31 & 0,14 \\
\hline Дивогляд & $-0,3$ & 0,94 & 0,17 & 0,41 & 24,1 & 0,96 & 0,77 & 0,06 & 0,01 \\
\hline Доказ & $-0,1$ & 0,84 & 0,17 & 0,41 & 21,6 & 1,16 & 0,77 & 0,29 & 0,05 \\
\hline Етикет & 0,3 & 2,36 & 1,15 & 1,07 & 46,5 & 0,37 & 5,23 & 0,33 & 0,38 \\
\hline Здобуток & 0,0 & 1,49 & 0,43 & 0,66 & 33,0 & 0,81 & 1,95 & 0,12 & 0,05 \\
\hline Інклюзив & $-0,2$ & 0,64 & 0,25 & 0,50 & 27,8 & 0,90 & 1,14 & 0,92 & 0,23 \\
\hline Козван & 0,4 & 0,75 & 0,11 & 0,33 & 13,7 & 1,81 & 0,50 & 0,36 & 0,04 \\
\hline Косар & 0,2 & 0,95 & 0,18 & 0,42 & 19,1 & 1,44 & 0,82 & 0,11 & 0,02 \\
\hline Модерн & $-0,1$ & 1,45 & 0,67 & 0,82 & 43,2 & 0,42 & 3,05 & 0,43 & 0,29 \\
\hline Парнас & $-0,6$ & 1,12 & 0,34 & 0,58 & 41,4 & 0,36 & 1,55 & 0,26 & 0,09 \\
\hline Перл & 0,3 & 1,49 & 0,43 & 0,66 & 28,7 & 1,11 & 1,95 & 0,09 & 0,04 \\
\hline Щедрий & $-0,4$ & 0,60 & 0,11 & 0,33 & 20,6 & 1,01 & 0,50 & 0,91 & 0,10 \\
\hline
\end{tabular}




\section{СІЛЬСЬКЕ ГОСПОДАРСТВО. РОСЛИННИЦТВО}

На думку А. А. Жученко [2], стабільність сорту може бути пов'язана або з високою пристосованістю кожного генотипу до різноманітних умов вирощування (індивідуальна буферність), або з пристосованістю кожного із групи генотипів, які складають сорт, до визначеного середовища (популяційна буферність).

$\mathrm{y}$ генетично гомогенній популяції (чистолінійний сорт або простий гібрид $\mathrm{F}_{1}$ ) буде переважати індивідуальна буферність, а в гетерогенній популяції буде проявлятися як індивідуальна, так і популяційна буферність.

Ступінь стабільності генотипу можна оцінити за ефектом ( $\left.\sigma \mathrm{CA} 3_{\mathrm{i}}\right)$ або варіансою $\left(\sigma^{2} \mathrm{CA} 3_{\mathrm{i}}\right)$ специфічної адаптивної здатності - чим нижче значення цих показників, тим стабільнішим є генотип. Окрім специфічної адаптивної здатності стабільність генотипів також можна оцінити за рівнем показника «відносна стабільність генотипу» $\left(\mathrm{S}_{\mathrm{gi}}\right)$, який $є$ аналогом коефіцієнта варіації $(\mathrm{Cv})$. Найбільш стабільними в наших дослідженнях виявилися сорти Щедрий $\left(\sigma \mathrm{CA} 3_{\mathrm{i}}=0,33\right.$; $\left.\mathrm{S}_{\mathrm{gi}}=20,6 \%\right)$, Козван $\left(\sigma \mathrm{CA} 3_{\mathrm{i}}=0,33 ; \mathrm{S}_{\mathrm{gi}}=13,7 \%\right)$, Алегро $\left(\sigma \mathrm{CA} 3_{\mathrm{i}}=0,35 ; \mathrm{S}_{\mathrm{gi}}=19,4 \%\right)$, Взірець $\left(\sigma \mathrm{CA} 3_{\mathrm{i}}=0,32 ; \mathrm{S}_{\mathrm{gi}}=18,8 \%\right)$.

Показник «відносна стабільність сорту» варіював від 13,7 \% до 46,5 \%. Практично всі генотипи, які мали низьку варіансу взаємодії з сере-

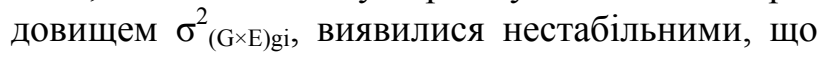
вказує на прояв дестабілізуючого ефекту. Показники коефіцієнта компенсації $\mathrm{K}_{\mathrm{gi}}$ вказують на наявність у досліджених сортів як компенсуючих $\left(\mathrm{K}_{\mathrm{gi}}=1,05-3,05\right)$, так і дестабілізуючих ефектів $\left(\mathrm{K}_{\mathrm{gi}}=0,50-0,86\right)$.

\section{БІБЛІОГРАФІЯ}

1. Жученко А. А. Роль генетической инженерии в адаптивной системе селекции растений / А. А. Жученко // Сельскохозяйственная биология. -2003 . - № 1.

2. Жученко А. А. Экологическая генетика культурных растений (адаптация, рекомбиногенез, агробиоценоз) / А. А. Жученко. - Кишинев : Штиинца. $-1980 .-588 \mathrm{c}$.

3. Кильчевский А. В. Экологическая селекция растений / А. В. Кильчевский, Л. В. Хотылева. Минск : Тэхнологія, 1997. $-372 \mathrm{c}$.

4. Марухняк А.Я. Кореляційні зв'язки між продуктивністю та параметрами екологічної адаптивності у зразків вівса / [А. Я. Марухняк, А. О. Дацько, Ю. А. Лісова, Г. І. Марухняк] // Передгірне та гірське землеробство і тваринниц-
Згідно 3 коефіцієнтом нелінійності $1_{\mathrm{gi}}$ у всіх генотипів реакція на середовище має лінійний характер $\left(1_{\mathrm{gi}} \leq 1\right)$.

Інтегральним показником, що дає змогу оцінити генотип за поєднанням продуктивності й стабільності урожаю, є селекційна цінність генотипу $\left(С Ц \Gamma_{\mathrm{i}}\right)$. Високі показники селекційної цінності генотипу мали сорти Косар та Вектор $(С Ц Г і=1,44$ та 1,52 відповідно), проте найвищу селекційну цінність мав генотип сорту Козван $\left(С Ц \Gamma_{\mathrm{i}}=1,77\right)$, який поєднував високу продуктивність та стабільний іï прояв у різних умовах вирощування $\left(\sigma \mathrm{CA} 3_{\mathrm{i}}=0,33 ; \mathrm{S}_{\mathrm{gi}}=13,7 \%\right)$, що $\epsilon$ найбільш важливим для сучасних сортів та гібридів сільськогосподарських культур.

\section{Висновки:}

1. Таким чином, методом дисперсійного аналізу визначено особливості впливу факторів та їх взаємодії на формування продуктивності рослини ячменю ярого.

2. Встановлено особливості умов пунктів екологічного випробування, в якості фонів для оцінки генотипів.

3. Внаслідок проведеного екологічного випробування сортів ячменю ярого селекції Інституту рослинництва ім. В. Я. Юр'єва НААН, виділено сорти 3 високою загальною і специфічною адаптивною здатністю за продуктивністю рослини, як найбільш цінний вихідний матеріал для селекції.

4. Виділено високоадаптивний сорт Козван, генотип якого забезпечував високий рівень прояву ознаки (продуктивності рослини) та стабільний його прояв.

тво. - Львів-Оброшино, 2014. - Вип. 56, Ч. І. C. $123-135$.

5. Солонечний П. М. Стабільність елементів продуктивності сортів ячменю ярого в екологічному випробуванні / [П. М. Солонечний, М. Р. Козаченко, Н. І. Васько, О. Г. Наумов, П. П. Дмитренко, О. Л. Коваленко] // Селекція і насінництво. - 2014. - Вип. 105. - С. 194-203.

6. Analysis of the genotype-by-environment interaction of spring barley tested in the Nordic Region of Europe : Relationships among statistics for grain yield / [M. Nurminiemi, S. Madsen, O. A. Rongli, A. Bjornstad, R. Ortiz]. - Euphytica. - 2002. - Volume 127. - P. 123-132.

7. Eberhart S.A. Stability parameters for comparing varieties / S. A. Eberhart, W. A. Russel // 
Crop. Sci., 1966.- Vol. 6. - № 1. - P. 36-40.

8. Kadi Z. Analysis of the genotype $\mathrm{x}$ environment interaction of barley grain yield (Hordeum vulgare L.) under semi-arid conditions / Z. Kadi, F. Adjel, H. Bouzerzour // Advances in Environmental Biology. - 2010. - Vol. 4 (1). - P. 34-40.
9. Lin C. S. Stability analysis: where do we stand? / C. S. Lin, M. R. Binns, L. P. Lefkovitch. - Crop Science. - 1986. - № 26. - P. 894-900.

10. Saad F. F. Parametric statistical methods for evaluating barley genotypes in multi-environment trials / F. F. Saad, A. A. El-Mohsen, I. H. Al-Soudan // World Essays Journal. - 2013. - Vol. 1 (4). - P. 125136. 